\begin{tabular}{|} 
Ambiente \& Água - An Interdisciplinary Journal of Applied Science \\
ISSN 1980-993X - doi:10.4136/1980-993X \\
www.ambi-agua.net \\
E-mail: ambi.agua@gmail.com
\end{tabular}

\title{
Evaluation of physicochemical water parameters in watersheds of southern Brazil
}

\author{
ARTICLES doi:10.4136/ambi-agua.2596
}

Received: 11 Jun. 2020; Accepted: 19 Aug. 2020

\author{
Marta Sória1 ${ }^{1 D}$; Vitor Emanuel Quevedo Tavares ${ }^{2}$; \\ Marília Alves Brito Pinto ${ }^{3}$; Lizete Stumpf $^{4 *(D)}$; \\ Daiane Zarnott ${ }^{5}$; Jéssica Bubolz ${ }^{6}$; ; Bernardo Gomes Nörenberg ${ }^{7}$ (iD
}

\footnotetext{
${ }^{1}$ Departamento de Anuência Ambiental. Secretaria de Qualidade Ambiental. Prefeitura Municipal de Pelotas, Avenida Domingos de Almeida, n 1490, CEP: 96085-470, Pelotas, RS, Brazil. E-mail: martilha@yahoo.com.br ${ }^{2}$ Faculdade de Agronomia Eliseu Maciel. Departamento de Engenharia Rural. Universidade Federal de Pelotas (UFPel), Caixa Postal 354, Campus Universitário, CEP: 96010-900, Pelotas, RS, Brazil. E-mail: vtavares@ufpel.edu.br

${ }^{3}$ Centro de Desenvolvimento Tecnológico. Departamento de Engenharia Hídrica. Universidade Federal de Pelotas (UFPel), Rua Gomes Carneiro, n 1, CEP: 96010-610, Pelotas, RS, Brazil. E-mail: ma.agro@ gmail.com ${ }^{4}$ Faculdade de Agronomia Eliseu Maciel. Departamento de Solos. Universidade Federal de Pelotas (UFPel), Campus Capão do Leão, Campus Universitário, s/n, CEP: 96160-000, Capão do Leão, RS, Brazil.

${ }^{5} 1^{\circ}$ Centro de Geoinformação. Exército Brasileiro, Rua Cleveland, n 250, CEP: 90850-240, Porto Alegre, RS, Brazil. E-mail: daiahzar@gmail.com

${ }^{6}$ Faculdade de Agronomia Eliseu Maciel. Universidade Federal de Pelotas (UFPel), Campus Capão do Leão, Campus Universitário, s/n, CEP: 96160-000, Capão do Leão, RS, Brazil. E-mail: jessicabubolz@gmail.com ${ }^{7}$ Programa de Pós-Graduação em Recursos Hídricos. Universidade Federal de Pelotas (UFPel), Rua Gomes Carneiro, n 1, CEP: 96010-610, Pelotas, RS, Brazil. E-mail: bernardo.norenberg@ hotmail.com *Corresponding author. E-mail: zete.stumpf@gmail.com
}

\begin{abstract}
Water-quality monitoring is one of the main instruments for water-resource management. This work therefore evaluated the water quality of the contribution basin of the Sinnott water treatment plant as well as the relationship between physicochemical water parameters, and analyzed the seasonal variation of water quality parameters as a function of rainfall. The study area encompassed the contribution basin of the Sinnott water treatment plant, formed mainly by the drainage areas of the Pelotas stream and its tributary, the Quilombo Stream, located in the city of Pelotas - Rio Grande do Sul, Brazil. A set of 118,368 data points for each stream was analyzed between 2007 and 2012. The following water quality parameters were evaluated: turbidity, temperature, color, $\mathrm{pH}$, hardness, dissolved oxygen, organic matter, and alkalinity. Results showed that dissolved oxygen and water $\mathrm{pH}$ values conformed with Brazilian legislation in the 6 years evaluated. However, water color was the parameter that remained the greatest number of days above the set limits, mainly in the Pelotas Stream. Result indicates the need for conservation actions in the catchment, especially considering the importance of color for the assessment of water quality for public supply, in terms of both treatment costs and of public health. Highest values for water color, turbidity, and organic matter coincided with the occurrence of the highest rainfall values. Agricultural activities may potentiate sedimentation in the contribution basin of the Sinnott water treatment plant.
\end{abstract}

keywords: color, organic matter, turbidity.

This is an Open Access article distributed under the terms of the Creative Commons Attribution License, which permits unrestricted use, distribution, and reproduction in any medium, provided the original work is properly cited. 


\section{Avaliação de parâmetros físico-químicos da água em bacia hidrográfica do sul do Brasil}

\section{RESUMO}

O monitoramento da qualidade da água consiste num dos principais instrumentos para gestão de recursos hídricos. O presente trabalho teve como objetivos: (i) avaliar a qualidade da água na bacia de contribuição da estação de tratamento de água de Sinnott bem como a relação entre os parâmetros fisioquímicos da água; e (ii) analisar a variação sazonal dos parâmetros de qualidade da água em função das chuvas. A área de estudo abrangeu a bacia de contribuição da estação de tratamento de água de Sinnott, formada principalmente pelas áreas de drenagem do córrego Pelotas e seu afluente, o córrego Quilombo, localizado na cidade de Pelotas. Um conjunto de 118.368 pontos de dados foi analisado entre 2007 e 2012. Os seguintes parâmetros de qualidade da água foram avaliados foram: turbidez, temperatura, cor, $\mathrm{pH}$, dureza, oxigênio dissolvido, matéria orgânica e alcalinidade. Os resultados mostraram que os valores de oxigênio dissolvido e pH da água estavam de acordo com a legislação brasileira nos 6 anos avaliados. Entretanto, a cor da água foi o parâmetro que permaneceu o maior número de dias acima dos limites estabelecidos, ocorrendo principalmente no córrego Pelotas. Esse resultado indica a necessidade de ações de conservação na bacia hidrográfica, principalmente considerando a importância da cor na avaliação da qualidade da água para abastecimento público, tanto em termos de custos de tratamento quanto de saúde pública. Os maiores valores de cor da água, turbidez e matéria orgânica coincidiram com a ocorrência dos maiores valores de precipitação. As atividades agrícolas podem potencializar a sedimentação na bacia de contribuição da estação de tratamento de água de Sinnott.

Palavras-chave: cor, matéria orgânica, turbidez.

\section{INTRODUCTION}

Water quality is one of the important issues in water-resource management (Sutadian et al., 2016). Water quality can be classified into three broad categories: physical, chemical and biological, and each category has several parameters (Swamee and Tyagi, 2007). These parameters must be associated with the characteristics of local water uses and relating quality objectives.

Rainfall information is important in the analysis of water quality, as it directly influences the flow and quality of a body of water. Rainfall intensities establish different levels of impacts on the soil and erosive processes of varying degrees that directly influence the rate of runoff (Fraga et al., 2012).

In agricultural systems where there is no adequate soil management, sediment runoff can be substantially altered in comparison to natural biomes (Alvarez et al., 2014; Torres et al., 2017). In Brazil, Taniwaki et al. (2017) observed higher concentrations of nitrate and suspended solids in the water quality of streams which drained sugarcane fields, mainly during the wet season. In China, Xiao et al. (2019) reported a presence of trace elements such as $\mathrm{Cr}, \mathrm{Pb}, \mathrm{Cd}$, $\mathrm{Cu}$, and $\mathrm{Ag}$ in rivers, mainly due to anthropogenic inputs. In contrast, when evaluating water bodies, Wang et al. (2017) described dominant pollutants such as $\mathrm{Zn}, \mathrm{Cd}$, and $\mathrm{Pb}$, making the water unsuitable for drinking in that area.

In Southern Brazil, the contribution basin of the Sinnott water treatment plant assists water for human consumption for over 328,275 inhabitants in Pelotas city (IBGE, 2010). Although the Autonomous Service of Pelotas Water Supply (SANEP) evaluates the physicochemical water parameters for later treatment, so far few studies have evaluated these parameters over the years, as well as the relationship between them; and the relation of these parameters with 
rainfall and use of the areas around the slopes of the basin. From this perspective, the present work evaluated water quality in the contribution basin of the Sinnott water treatment plant and the relationship between physicochemical water parameters, and analyzed the seasonal variation of water quality parameters as a function of rainfall.

\section{MATERIAL AND METHODS}

\subsection{Study area}

The study area was the contribution basin of the Sinnott water treatment plant, which is located in the southeast of Rio Grande do Sul State, between the geodetic coordinates $31^{\circ} 30^{\prime}$ a $34^{\circ} 35^{\prime} \mathrm{S}$ e $53^{\circ} 31^{\prime}$ a $55^{\circ} 15^{\prime} \mathrm{O}$. The basin is formed mainly by the drainage areas of the Pelotas Stream and its tributary, the Quilombo Stream (Figure 1). The main water uses of the contribution basin are irrigation, human consumption, and animal-related.

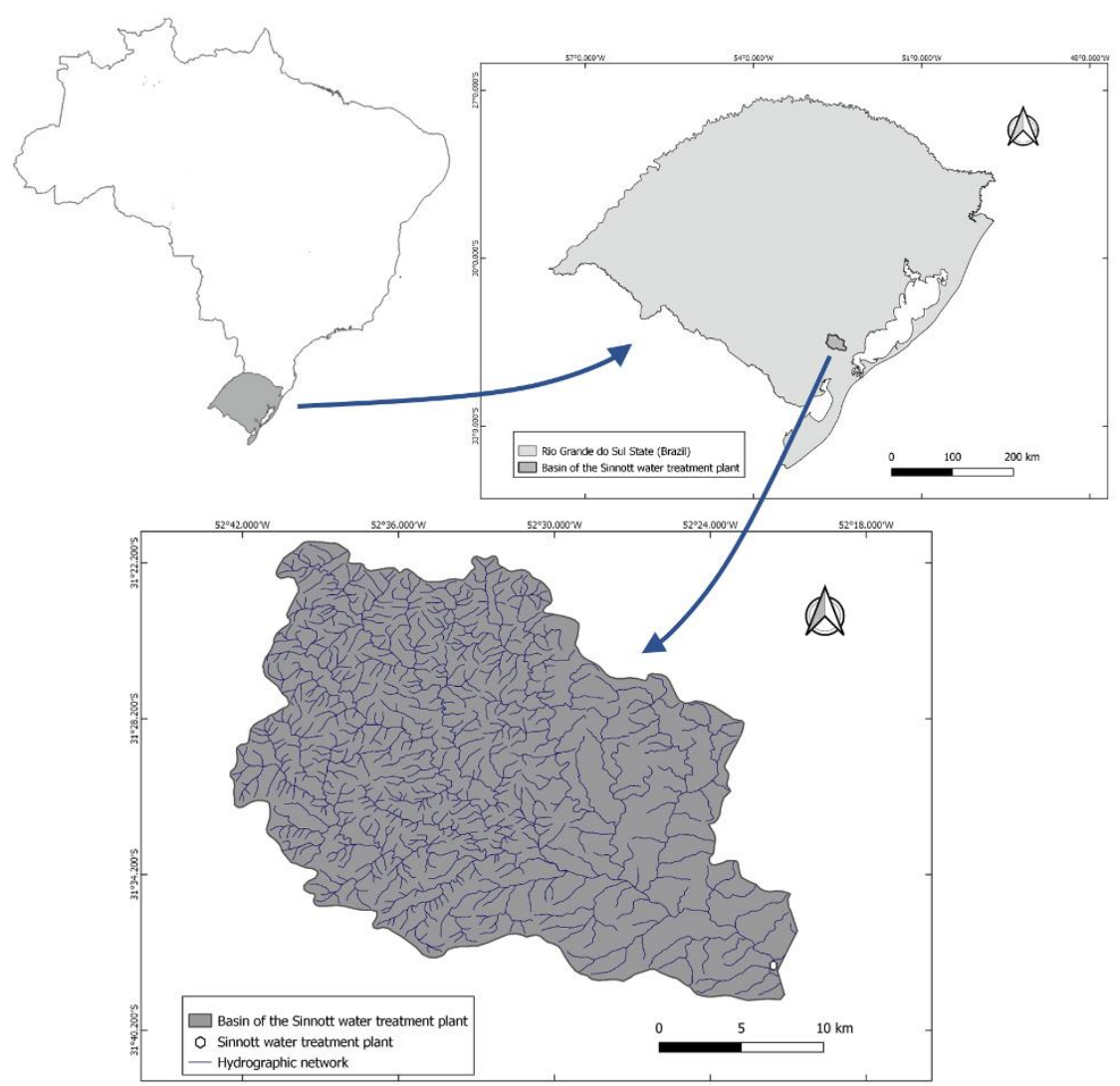

Figure 1. Basin of the Sinnott water treatment plant, located in Pelotas city, Rio Grande do Sul State, Southern Brazil.

According to the Köppen system, the climate of the region was classified as humid subtropical (Cfa), with an average annual temperature of $17^{\circ} \mathrm{C}$ and an average annual rainfall of 1,400 mm (Alvares et al., 2013). The main soil classes around the contribution basin were categorized as Ultisols, Inceptisols, Entisols, Alfisols, and Gleisols (Flores et al., 2009).

\subsection{Sampling and analysis of water quality parameters}

The data used in this study are the results of the water monitoring carried out by SANEP in the Pelotas and Quilombo Streams. SANEP provided data in handwritten spreadsheets with the following water quality parameters: turbidity, temperature, color, $\mathrm{pH}$, hardness, dissolved oxygen, organic matter, and alkalinity. The data set relates the hourly evaluation of each parameter during the period 2007 to 2012. 
Water samples were collected at two locations at the Sinnott water treatment plant

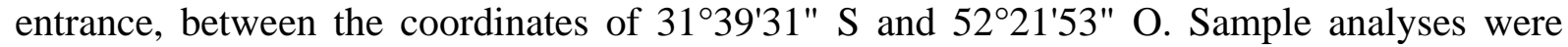
carried out by SANEP, according to the Standard Methods for the Examination of Water and Wastewater (APHA et al., 1998).

The main water uses of the Sinnott contribution basin are animal drinking, irrigation, and, after conventional treatment, human consumption. Thus, the studied parameters must comply with CONAMA Resolution $\mathrm{n}^{\circ} 357$ of 03/17/2005, in its Article 42, which classifies freshwater bodies as those of the present study as Class 2. Physicochemical water parameters were compared to the Brazilian legislation for freshwaters, specifically to Class 2 (CONAMA, 2005), according to Table 1 .

Table 1. Physicochemical water parameters suitable for freshwaters (Class 2) according to the Brazilian legislation (CONAMA Resolution $\mathrm{N}^{\circ}$ 357, March 17, 2005).

\begin{tabular}{ccc}
\hline Parameter & Unity & Class 2 \\
\hline Color & $\mathrm{mg} \mathrm{Pt} \mathrm{L}^{-1}$ & until 75 \\
Turbidity & UNT & until 100 \\
dissolved oxygen & $\mathrm{mg} \mathrm{L}^{-1} \mathrm{de} \mathrm{O}_{2}$ & not less than 5.0 \\
$\mathrm{pH}$ & - & from 6.0 to 9.0 \\
\hline
\end{tabular}

Rainfall data were obtained at Ponte Cordeiro de Farias Pluviometric Station (31 $34^{\prime} 26^{\prime \prime} \mathrm{S}$ and $\left.52^{\circ} 27^{\prime} 47^{\prime \prime} \mathrm{W}\right)$, which is inserted into the watershed boundary of the Pelotas Stream, operated by the National Water Agency of Brazil (ANA) and the Brazilian Mineral Resources Research Company (CPRM). Monthly rainfall series were organized based on the historical series available in a database on the Hidroweb- Hydrological Information System homepage.

\subsection{Statistical analyses}

Descriptive analysis of all data sets was performed by classical statistics, determining the range of values, and calculating their mean. Principal components analysis (PCA) was used to group the water quality indicators, and to therefore explain the relation between them. Pearson correlation analysis was used to verify the relationship between water quality indicators and rainfall.

\section{RESULTS AND DISCUSSION}

The maximum and minimum values of water temperature followed the seasonal trend, corresponding to the summer and winter seasons, in both the Pelotas and Quilombo Streams between 2007 and 2012 (Table 2). According to Alvarenga et al. (2012), temperature varies according to the climatic regime, and superficial water resources show seasonal and diurnal variations, making water temperature the parameter most influenced by flow seasonality.

The highest mean turbidity values were observed in the Pelotas Stream (Table 2), possibly due to the larger area of its contribution basin.

Similar to turbidity, the highest water color values were also observed in the Pelotas Stream, with a mean ranging from 65 to $180 \mathrm{mg} \mathrm{Pt} \mathrm{L}^{-1}$ between 2007 and 2012. In the Quilombo Stream, the annual average observed was between 53 and $132 \mathrm{mg} \mathrm{Pt} \mathrm{L}^{-1}$ (Table 2). The higher color values are due possibly to the organic residues of plants deposited in the stream, which promote organic matter degradation by bacteria and by forming humic and fulvic acid. Additionally, the erosive processes of agricultural areas located around the stream promote the transport of sediment, also leading to alterations in the color of the water (Oliveira et al., 2010). 
Table 2. Minimum (Min), maximum (Max) and mean values of the water quality parameters in Pelotas and Quilombo Streams between 2007 and 2012.

\begin{tabular}{|c|c|c|c|c|c|c|c|c|c|}
\hline Parâmetros & Min & Max & Mean & Min & Máx & Média & Min & Máx & Média \\
\hline & \multicolumn{3}{|c|}{2007} & \multicolumn{3}{|c|}{2008} & \multicolumn{3}{|c|}{2009} \\
\hline Water Temperature $\left({ }^{\circ} \mathrm{C}\right)$ & 6.7 & 30.0 & 18.5 & 9.0 & 28.0 & 18.2 & 7.5 & 27.0 & 18.2 \\
\hline Turbidity (UNT) & 3.1 & 160.8 & 18.5 & 2.6 & 146.1 & 20.4 & 4.7 & 111.5 & 29.3 \\
\hline Color $\left(\mathrm{mg} \mathrm{Pt} \mathrm{L}^{-1}\right)$ & 14.0 & 350 & 70.0 & 10.0 & 320.0 & 65.0 & 20.0 & 1037.0 & 180.0 \\
\hline $\mathrm{pH}$ & 6.3 & 7.7 & 7.0 & 6.6 & 7.6 & 7.1 & 6.0 & 7.6 & 7.0 \\
\hline Hardness $\left(\mathrm{CaCO}_{3} \mathrm{mg} \mathrm{L}^{-1}\right)$ & 7.5 & 25.0 & 17.3 & 12.0 & 29.0 & 18.1 & 6.0 & 23.0 & 15.1 \\
\hline Alkalinity $\left(\mathrm{CaCO}_{3} \mathrm{mg} \mathrm{L}^{-1}\right)$ & 11.0 & 38.2 & 23.8 & 9.2 & 37.2 & 23.0 & 11.0 & 28.1 & 21.1 \\
\hline $\mathrm{CO}_{2}$ free $\left(\mathrm{mg} \mathrm{L}^{-1}\right)$ & 2.8 & 28.8 & 8.3 & 2.4 & 12.0 & 5.8 & 3.2 & 14.4 & 6.2 \\
\hline Dissolved oxygen $\left(\mathrm{mg} \mathrm{L}^{-1}\right)$ & 5.4 & 11.6 & 8.9 & 6.5 & 10.4 & 8.3 & 5.4 & 11.1 & 8.3 \\
\hline \multirow[t]{2}{*}{ Organic matter $\left(\mathrm{mg} \mathrm{L}^{-1}\right)$} & 1.4 & 16.0 & 5.1 & 1.5 & 16.6 & 4.8 & 1.0 & 17.2 & 5.1 \\
\hline & \multicolumn{3}{|c|}{2010} & \multicolumn{3}{|c|}{2011} & \multicolumn{3}{|c|}{2012} \\
\hline Water Temperature $\left({ }^{\circ} \mathrm{C}\right)$ & 9.0 & 29.0 & 19.3 & 8.0 & 28.0 & 19.5 & 9.0 & 29.0 & 20.3 \\
\hline Turbidity (UNT) & 5.3 & 151.4 & 24.3 & 6.9 & 181.3 & 32.2 & 6.1 & 274.4 & 36.0 \\
\hline Color (mg Pt L $\left.\mathrm{L}^{-1}\right)$ & 31.0 & 1410.0 & 135.0 & 29.0 & 785.0 & 121.0 & 21.0 & 720.0 & 109.0 \\
\hline $\mathrm{pH}$ & 5.8 & 7.5 & 7.1 & 6.5 & 7.8 & 7.0 & 6.3 & 7.3 & 6.9 \\
\hline Hardness $\left(\mathrm{CaCO}_{3} \mathrm{mg} \mathrm{L}^{-1}\right)$ & 12.0 & 28.0 & 17.2 & 8.5 & 22.0 & 16.5 & 14.0 & 29.0 & 20.5 \\
\hline Alkalinity $\left(\mathrm{CaCO}_{3} \mathrm{mg} \mathrm{L}^{-1}\right)$ & 13.8 & 35.0 & 25.2 & 12.9 & 33.7 & 23.1 & 10.1 & 33.0 & 25.6 \\
\hline $\mathrm{CO}_{2}$ free $\left(\mathrm{mg} \mathrm{L}^{-1}\right)$ & 3.2 & 18.0 & 5.3 & 3.2 & 11.6 & 5.1 & 3.2 & 16.0 & 6.2 \\
\hline Dissolved oxygen $\left(\mathrm{mg} \mathrm{L}^{-1}\right)$ & 5.5 & 11.8 & 9.1 & 5.3 & 10.7 & 8.4 & 5.1 & 17.0 & 8.5 \\
\hline \multirow[t]{2}{*}{ Organic matter $\left(\mathrm{mg} \mathrm{L}^{-1}\right)$} & 1.3 & 27.8 & 4.7 & 1.5 & 19.6 & 4.6 & 1.5 & 18.4 & 4.7 \\
\hline & \multicolumn{3}{|c|}{2007} & \multicolumn{3}{|c|}{2008} & \multicolumn{3}{|c|}{2009} \\
\hline Water Temperature $\left({ }^{\circ} \mathrm{C}\right)$ & 8.0 & 27.0 & 18.4 & 9.0 & 28.0 & 19.0 & 9.7 & 28.0 & 19.7 \\
\hline Turbidity (UNT) & 0.6 & 116.6 & 14.7 & 1.6 & 313.1 & 20.6 & 1.6 & 564.3 & 25.5 \\
\hline Color (mg Pt L $\left.\mathrm{L}^{-1}\right)$ & 8.0 & 1037.0 & 80.0 & 9.0 & 826.0 & 73.0 & 5.0 & 886.0 & 65.0 \\
\hline $\mathrm{pH}$ & 6.1 & 7.8 & 7.3 & 6.4 & 7.6 & 7.2 & 6.5 & 7.6 & 7.2 \\
\hline Hardness $\left(\mathrm{CaCO}_{3} \mathrm{mg} \mathrm{L}^{-1}\right)$ & 13.0 & 29.0 & 17.1 & 8.0 & 24.0 & 17.1 & 14.0 & 30.0 & 20.4 \\
\hline Alkalinity $\left(\mathrm{CaCO}_{3} \mathrm{mg} \mathrm{L}^{-1}\right)$ & 12.8 & 36.1 & 24.7 & 13.5 & 31.3 & 23.3 & 12.8 & 30.6 & 24.7 \\
\hline $\mathrm{CO}_{2}$ free $\left(\mathrm{mg} \mathrm{L}^{-1}\right)$ & 2.0 & 12.0 & 4.9 & 2.4 & 8.0 & 4.5 & 2.4 & 12.0 & 5.1 \\
\hline Dissolved oxygen $\left(\mathrm{mg} \mathrm{L}^{-1}\right)$ & 6.4 & 12.9 & 9.1 & 6.1 & 10.6 & 8.6 & 5.8 & 11.3 & 8.6 \\
\hline \multirow[t]{2}{*}{ Organic matter $\left(\mathrm{mg} \mathrm{L}^{-1}\right)$} & 0.8 & 19.8 & 3.2 & 0.8 & 20.0 & 3.1 & 0.8 & 17.8 & 3.0 \\
\hline & \multicolumn{3}{|c|}{2010} & \multicolumn{3}{|c|}{2011} & \multicolumn{3}{|c|}{2012} \\
\hline Water Temperature $\left({ }^{\circ} \mathrm{C}\right)$ & 8.0 & 29.0 & 18.1 & 10.0 & 28.0 & 18.4 & 6.0 & 26.0 & 17.6 \\
\hline Turbidity (UNT) & 1.7 & 193.2 & 14.8 & 1.4 & 186.2 & 16.4 & 1.4 & 125.5 & 21.6 \\
\hline Color (mg Pt L $\left.\mathrm{L}^{-1}\right)$ & 15.0 & 400.0 & 56.0 & 10.0 & 350.0 & 53.0 & 8.0 & 1808.0 & 132.0 \\
\hline $\mathrm{pH}$ & 6.4 & 7.5 & 7.1 & 6.6 & 7.7 & 7.3 & 6.2 & 7.6 & 7.2 \\
\hline Hardness $\left(\mathrm{CaCO}_{3} \mathrm{mg} \mathrm{L}^{-1}\right)$ & 5.0 & 27.0 & 17.0 & 5.7 & 20.0 & 9.1 & 8.0 & 20.0 & 15.1 \\
\hline Alkalinity $\left(\mathrm{CaCO}_{3} \mathrm{mg} \mathrm{L}^{-1}\right)$ & 12.0 & 37.0 & 23.5 & 12.7 & 35.0 & 22.8 & 10.0 & 28.4 & 21.3 \\
\hline $\mathrm{CO}_{2}$ free $\left(\mathrm{mg} \mathrm{L}^{-1}\right)$ & 2.4 & 22.0 & 5.8 & 2.8 & 12.0 & 4.4 & 2.8 & 14.0 & 4.8 \\
\hline Dissolved oxygen $\left(\mathrm{mg} \mathrm{L}^{-1}\right)$ & 6.3 & 12.1 & 9.2 & 4.0 & 10.7 & 8.5 & 6.2 & 12.0 & 8.5 \\
\hline Organic matter $\left(\mathrm{mg} \mathrm{L}^{-1}\right)$ & 0.9 & 17.3 & 3.7 & 0.0 & 9.2 & 1.7 & 0.4 & 18.5 & 3.6 \\
\hline
\end{tabular}


Values for $\mathrm{pH}$ ranged between 6.0 and 8.0 in both the Pelotas and Quilombo Streams, considered appropriate according to the Brazilian legislation (Table 2). These results could reflect either the buffering capacity by the ecosystem (Siqueira et al., 2012) or could be potentially related to the fact that soil use and occupation around the analyzed points were essentially agricultural, which in general does not tend to affect $\mathrm{pH}$ values. Similar results were observed by Piratoba et al. (2017). According to Derisio (2016), changes in the pH values of water are caused by industrial wastes.

Mean water hardness values for Pelotas Stream ranged from 15.1 to $20.5 \mathrm{mg} \mathrm{CaCO}_{3} \mathrm{~L}^{-1}$, whereas in the Quilombo Stream values ranged from 9.1 to $20.4 \mathrm{mg} \mathrm{CaCO}_{3} \mathrm{~L}^{-1}$ between 2007 and 2012 (Table 2). Similar results were observed by Estrela et al. (2010), when evaluating irrigation water quality in family farms located near the present study, probably due to the presence of the same soil class (Ultisols) in the area around the stream. In both streams, the hardness values were below $50 \mathrm{mg} \mathrm{CaCO}_{3} \mathrm{~L}^{-1}$ (Table 2) which classifies the water as soft and low-risk to cause damage to the irrigation system.

Water alkalinity varied between 21.1 and $25.6 \mathrm{mg} \mathrm{L}^{-1}$ in the Pelotas Stream, and 21.3 and $24.7 \mathrm{~m} \mathrm{~L}^{-1}$ in the Quilombo Stream (Table 2). Water hardness and alkalinity can be altered by seasonality and location of sampling points (Piratoba et al, 2017). According to Von Sperling (2007), the main constituents of alkalinity are bicarbonates $\left(\mathrm{HCO}_{3}^{-}\right)$and hydroxides $\left(\mathrm{OH}^{-}\right)$, which vary according to $\mathrm{pH}(\mathrm{pH}>9.4$ : hydroxides and carbonates; $\mathrm{pH}$ between 8.3 and 9.4: carbonates and bicarbonates; $\mathrm{pH}$ between 4.4 and 8.3: only bicarbonates). The water $\mathrm{pH}$ in the present study remained around 7.0 (Table 2), corresponding to a greater presence of bicarbonates in the Pelotas and Quilombo Streams.

The mean values for $\mathrm{CO}_{2}$ ranged from 5.1 to $8.3 \mathrm{mg} \mathrm{L}^{-1}$ in the Pelotas Stream, whereas in the Quilombo Stream values ranged from 4.4 to $5.8 \mathrm{mg} \mathrm{L}^{-1}$ between 2007 and 2012. In general, the Pelotas Stream showed higher free $\mathrm{CO}_{2}$ values in water, possibly due to higher organic matter values in comparison with the Quilombo Stream (Table 2).

The waters classified as Class 2 must have dissolved oxygen concentrations greater than 5 $\mathrm{mg} \mathrm{L}^{-1}$ (Table 1); it is observed that in all evaluated years the average values of dissolved oxygen exceeded the minimum stipulated value (Table 2). The highest values of dissolved oxygen were observed in the Quilombo Stream between 2007 and 2012, possibly due to lower values of organic matter (Table 2). According to Siqueira and Aprile (2013), higher organic matter content in water can lead to oxidation-reduction reactions, as oxygen is used as the final acceptor of electrons during the processes associated with organic material degradation.

Between 2007 and 2012, the mean organic matter values ranged from 4.6 to $5.1 \mathrm{mg} \mathrm{L}^{-1}$ in the Pelotas Stream, whereas in the Quilombo Stream values ranged from 1.7 to $3.7 \mathrm{mg} \mathrm{L}^{-1}$. It should be emphasized that, in all the evaluated years, the Pelotas Stream presented higher organic matter content in comparison to the Quilombo Stream (Table 2). Bezerra Lopes et al. (2008) mention the increase of primary production promoting the generation of a large amount of particulate organic material, resulting in water turbidity with a tendency towards higher values, as observed in the present study. In terms of annual average values, higher organic matter content was found in the Pelotas Stream, leading to higher turbidity and water color values as a consequence (Table 2).

Only in the Quilombo Stream in $0.3 \%$ of the days of 2008, the oxygen dissolved values did not meet the values stipulated by legislation (Table 3 ). This may be related to temperature, since in general the higher the minimum water temperature, the lower the dissolved oxygen.

Turbidity values for both the Pelotas and Quilombo Streams were found to be higher than 100 UNT during the period from 2007 to 2011, in less than 3\% of the days of each year. On the other hand, in 2012 turbidity values exceeded the limits of the Brazilian legislation in 4.6 and $5.5 \%$ of the days of each year, for the Pelotas and Quilombo Streams, respectively (Table 3). The increased turbidity values may be related to the activity related to sand mining, which 
generally promotes silting of the Pelotas slopes due to the sediment extraction, as well as due to the use of granite stones and Quarry fines, commonly used as a base for the roads illegally constructed on the stream banks.

Higher color values in the Pelotas Stream were observed in around $30 \%$ of the days in 2007 and 2008, above the limit established by the legislation, whereas from 2009 to 2012 the color values exceeded $75 \mathrm{mg} \mathrm{Pt} \mathrm{L}^{-1}$ in over $50 \%$ of the days of each year (Table 3).

Considering all the water quality parameters evaluated, principal components analysis revealed that these factors had an accumulated eigenvalue of $58.95 \%$ for the Pelotas Stream and $54.07 \%$ for the Quilombo Stream. The first main component resulted from a linear combination of the 9 variables studied, and explained $37.18 \%$ and $34.03 \%$ of the total variance, whereas the second component explained $21.76 \%$ and $20.05 \%$ for the Pelotas and Quilombo Streams, respectively.

Table 3. Percentage of days in which the dissolved oxygen, turbidity, color and $\mathrm{pH}$ values exceeded the values suitable for freshwaters (Class 2) according to Brazilian legislation (CONAMA Resolution $N^{\circ} 357$, March 17, 2005).

\begin{tabular}{|c|c|c|c|c|c|c|}
\hline \multirow{2}{*}{ Parameters } & \multicolumn{6}{|c|}{ Days (\%) } \\
\hline & 2007 & 2008 & 2009 & 2010 & 2011 & 2012 \\
\hline & \multicolumn{6}{|c|}{ PELOTAS STREAM } \\
\hline Dissolved oxygen $\left(\mathrm{mg} \mathrm{L}^{-1}\right)$ & 0.0 & 0.0 & 0.0 & 0.0 & 0.0 & 0.0 \\
\hline Turbidity (UNT) & 1.1 & 0.5 & 0.8 & 1.1 & 2.7 & 4.6 \\
\hline Color $\left(\mathrm{mgPt} \mathrm{L}^{-1}\right)$ & 30.1 & 30.6 & 76.2 & 67.4 & 60.0 & 54.9 \\
\hline \multirow[t]{2}{*}{$\mathrm{pH}$} & 0.0 & 0.0 & 0.0 & 1.1 & 0.0 & 0.0 \\
\hline & \multicolumn{6}{|c|}{ QUILOMBO STREAM } \\
\hline Dissolved oxygen $\left(\mathrm{mg} \mathrm{L}^{-1}\right)$ & 0.0 & 0.3 & 0.0 & 0.0 & 0.0 & 0.0 \\
\hline Turbidity (UNT) & 1.1 & 2.2 & 2.2 & 0.5 & 1.4 & 5.5 \\
\hline Color $\left(\mathrm{mgPt} \mathrm{L}^{-1}\right)$ & 17.8 & 19.4 & 44.1 & 24.7 & 22.2 & 17.8 \\
\hline $\mathrm{pH}$ & 0.0 & 0.0 & 0.0 & 0.0 & 0.0 & 0.0 \\
\hline
\end{tabular}

The first component positively correlated the variables color, organic matter, turbidity, and $\mathrm{CO}_{2}$, particularly the turbidity parameter, which presented the highest values of correlation with the first component in the Pelotas (Figure 2a) and Quilombo (Figure 2b) Streams. Therefore the physical parameters related to the transport of sediments and their effect on the concentration of $\mathrm{CO}_{2}$ in the waters. The soil carried to the river directly impacts water color and turbidity, and the soil organic matter increases the $\mathrm{CO}_{2}$ concentrations, since, in the organic matter oxidation process by aerobic microorganisms, there is the release of carbon dioxide. For both the Pelotas (Figure 2a) and the Quilombo (Figure 2b) Streams, the first component negatively correlated the parameters that are more related to the intrinsic characteristics of the basin, such as climate (water temperature), geomorphology (alkalinity and hardness), soil types, and uses ( $\mathrm{pH}$ and dissolved oxygen).

The second component was positively correlated with parameters such as water temperature, hardness, alkalinity, $\mathrm{pH}$, organic matter, color, turbidity, and negatively correlated with dissolved oxygen (Figure 2a, b). Water temperature and dissolved oxygen showed the highest correlations, and the relationship between them was inversely proportional. Silva et al. (2009) also observed lower water temperatures as directly linked to higher concentrations of dissolved oxygen. According to Post et al. (2018), water temperature is the primary regulating metric that determines how much dissolved oxygen water can hold; dissolved oxygen is inversely dependent on water temperature. Increases in water temperature would thus further reduce dissolved oxygen and negatively impact water quality. 


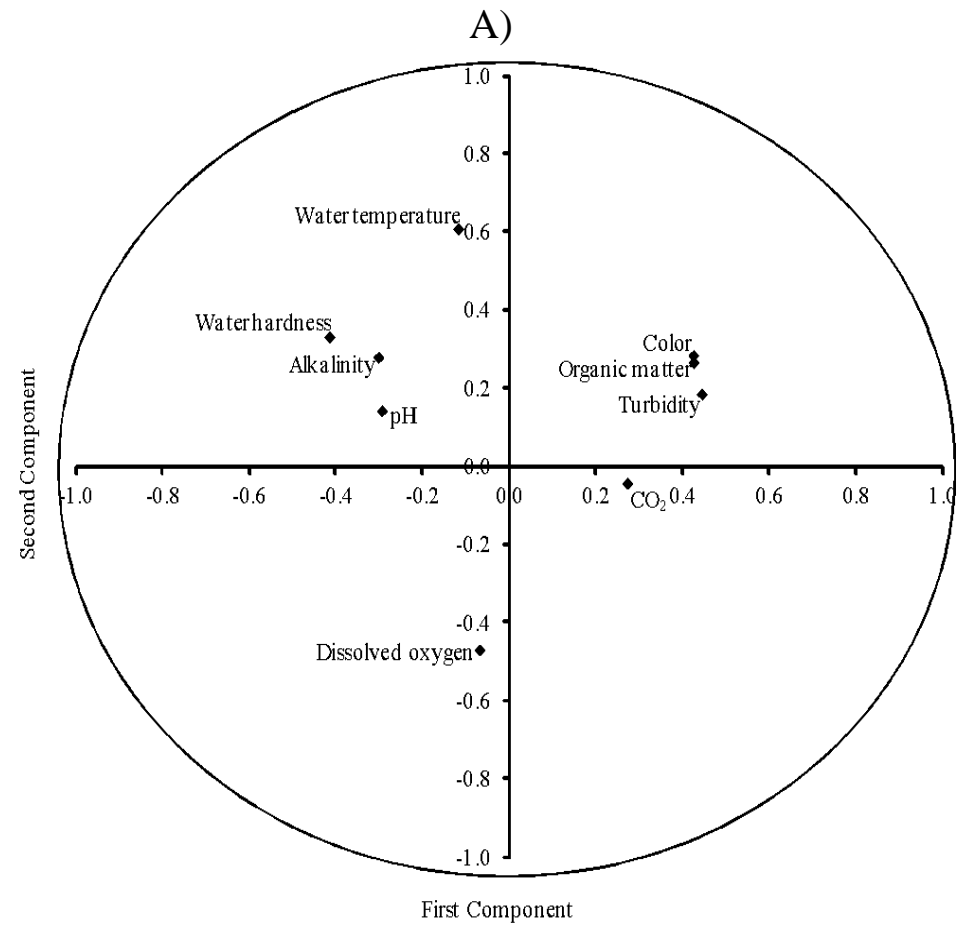

B)

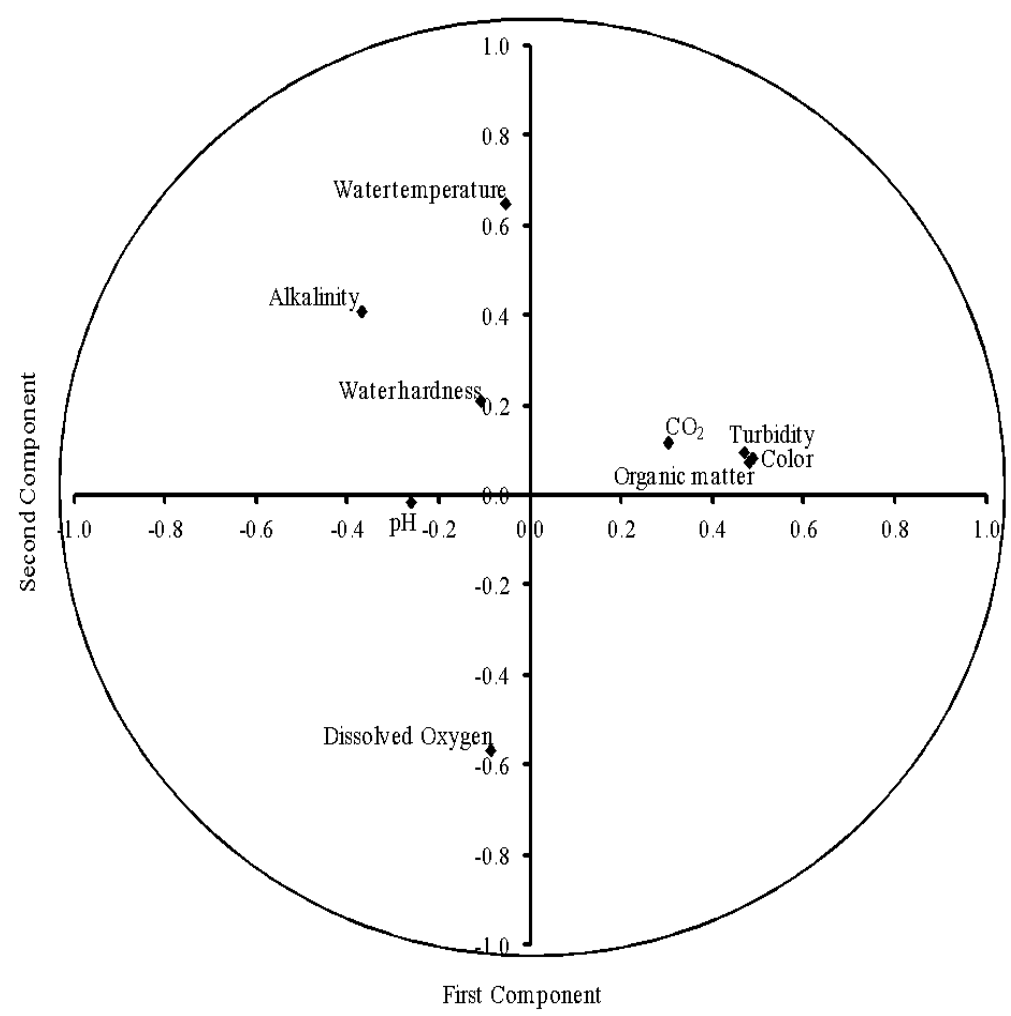

Figure 2. Multivariate analysis between water quality parameters of Pelotas (a) and Quilombo (b) Streams.

Pearson correlation values between the monthly means of the water quality parameters of the Pelotas and Quilombo Streams and the monthly averages of rainfall are found in Table 4. A significant positive correlation between turbidity, color, and organic matter with rainfall was observed in both of the studied streams. Fraga et al. (2012) and Silva et al. (2009) also observed a positive relation between turbidity values and rainfall accumulated in water sources in 
different regions of Brazil, indicating the impacts resulting from land use. Similar results were observed by Luíz et al. (2012), which found high color values (greater than $75 \mathrm{mg} \mathrm{Pt} \mathrm{L}^{-1}$ ) on days when rainfall was equal to or greater than $25 \mathrm{~mm}$. This can happen because rainfall causes erosion and the runoff of water into the rivers. That increases turbidity, color, and organic matter content in the waters.

Table 4. Pearson correlation between the monthly means of the water quality parameters of the Pelotas and Quilombo Streams and the monthly averages of rainfall.

\begin{tabular}{|c|c|c|c|c|c|c|c|c|c|}
\hline & $\begin{array}{c}\text { Water } \\
\text { Temperature }\end{array}$ & Turbidity & Color & $\mathrm{pH}$ & $\begin{array}{c}\text { Water } \\
\text { Hardness }\end{array}$ & Alkalinity & $\begin{array}{l}\text { Free } \\
\mathrm{CO}_{2}\end{array}$ & $\begin{array}{l}\text { Oxygen } \\
\text { dissolved }\end{array}$ & $\begin{array}{c}\text { Organic } \\
\text { matter }\end{array}$ \\
\hline & \multicolumn{9}{|c|}{ PELOTAS STREAM } \\
\hline \multirow[t]{2}{*}{ Rainfall } & $0.37^{\mathrm{NS}}$ & $0.52 *$ & $0.74 *$ & $-0.31^{\mathrm{NS}}$ & $-0.01^{\mathrm{NS}}$ & $0.31^{\mathrm{NS}}$ & $0.23^{\mathrm{NS}}$ & $-0.43^{\mathrm{NS}}$ & $0.54^{*}$ \\
\hline & \multicolumn{9}{|c|}{ QUILOMBO STREAM } \\
\hline Rainfall & $0.20^{\mathrm{NS}}$ & $0.62 *$ & $0.92 * * *$ & $-0.52^{\mathrm{NS}}$ & $-0.49^{\mathrm{NS}}$ & $0.30^{\mathrm{NS}}$ & $0.43^{\mathrm{NS}}$ & $-0.20^{\mathrm{NS}}$ & $0.75^{* *}$ \\
\hline
\end{tabular}

NS: no significant; $* \mathrm{p}<0.05 ; * * \mathrm{p}<0.01 ; * * * \mathrm{p}<0.1 \%$.

Fonseca and Salvador (2005) observed a decrease in the values of dissolved oxygen during periods of rainfall, related to an increase of organic matter transported on the soil surface by rain. The positive correlation between organic matter and rainfall was observed in both streams analyzed in the present study (Table 4).

The high values of water turbidity and color, sometimes higher than the limit in Brazilian legislation, in both Pelotas and Quilombo Streams, as well as the positive and significant correlation of these parameters with rainfall, can be associated with agricultural activities carried out in the basin area. During soil preparation for the implantation of summer crops in conventional planting areas, the soil is uncovered and disaggregated due to plowing and harrowing operations; its particles are therefore easily carried by rainwater. The summer crops implanted in the region (corn, soy, and tobacco) are not grown, most of the time, in conservationist soil management systems; consequently, little vegetative cover exists, leaving a large area of uncovered soil. This facilitates the transport of soil particles, fertilizers and pesticides by rainwater.

\section{CONCLUSIONS}

Values of $\mathrm{pH}$ and dissolved oxygen of water conformed with Brazilian legislation for the 6 years evaluated.

Concerning the values put forth by the Brazilian legislation, watercolor was the parameter that remained above the proposed limit for the greatest number of days, occurring mainly in the Pelotas Stream. Such findings indicate the need for soil conservation actions in the area of the contribution basin.

The highest values of color, turbidity, and organic matter occurred when the highest rainfall values were observed, showing a probable sediment transport effect in the basin. Agricultural activities may potentiate sedimentation in the contribution basin of the Sinnott water treatment plant.

\section{REFERENCES}

ALVARENGA, L. A.; MARTINS, M. P. P.; CUARTAS, L. A.; PENTEADO, V. A.; ANDRADE, A. Estudo da qualidade e quantidade da água em microbacia, afluente do rio Paraíba do Sul - São Paulo, após ações de prevenção ambiental. Revista Ambiente \& Água, n. 3, p. 228-240, 2012. https://doi.org/10.4136/ambi-agua.987 
ALVARES, C. A.; STAPE, J. L.; SENTELHAS, P. C.; GONÇALVES, J. L. M.; SPAROVEK, G. Köppen's climate classification map for Brazil. Meteorologische Zeitschrift, n. 6, p. 711-728, 2013. https://doi.org/10.1127/0941-2948/2013/0507

ALVAREZ, J. W. R.; PELLEGRINI, A.; KOCHEM, M. L.; SCHAEFER, G. L.; CAPOANE, V.; TIECHER, T.; FORNARI, M. R.; DOS SANTOS, D. R. Erosão hídrica e perda de sedimento, água e nutrientes durante eventos pluviais em duas bacias hidrográficas rurais. Investigación Agraria, n. 2, p. 113-123, 2014.

APHA; AWWA; WEF. Standard Methods for the Examination of Water and Wastewater. 20. ed. Washington, 1998.

BEZERRA LOPES, F.; SANTOS TEIXEIRA, A. D.; ANDRADE, E. M. D.; NASCIMENTO AQUINO, D. D.; PEREIRA ARAÚJO, L. D. F. Mapa da qualidade das águas do rio Acaraú, pelo emprego do IQA e Geoprocessamento. Revista Ciência Agronômica, n. 3, p. 392-402, 2008.

CONAMA (Brasil). Resolução n 357 de 17 de março de 2005. Dispõe sobre a classificação dos corpos de água e diretrizes ambientais para o seu enquadramento, bem como estabelece as condições e padrões de lançamento de efluentes, e dá outras providências. Diário Oficial [da] União: seção 1, Brasília, DF, n. 053, p. 58-63, 18 mar. 2005.

DERISIO, J. C. Introdução ao controle de poluição ambiental. 4. ed. São Paulo: Oficina de Textos, 2016.

ESTRELA, C. C.; TAVARES, V. E. Q.; TIMM, L. C.; REISSER JUNIOR, C.; MATTOS, M. L. T.; PEREIRA, G. C.; VENZKE, C. D. Caracterização das Fontes de Captação de Água Utilizadas para a Irrigação na Cadeia Produtiva de Morangos, no Município de Turuçu, RS. Current Agricultural Science and Technology, n. 1-4, p. 143-147, 2010.

FLORES, C. A.; FILIPPINI ALBA, J. M.; WREGE, M. S. Zoneamento agroclimático do eucalipto para o Estado do Rio Grande do Sul e edafoclimático na região do Corede Sul- RS. Pelotas: Embrapa Clima Temperado, 2009. 87p.

FONSECA, H. S.; SALVADOR, N. N. B. Estudo integrado da qualidade das águas da bacia hidrográfica do Rio Bonito em Descalvado-SP. Revista do Instituto Adolfo Lutz, n. 2, p. 179-185, 2005.

FRAGA, R. S.; TAVARES, V. E. Q.; TIMM, L. C.; ESTRELA, C. C.; BARTELS, G. K. Influência da precipitação sobre parâmetros de qualidade da água utilizada para irrigação do morangueiro no município de Turuçu-RS. Current Agricultural Science and Technology, n. 1, p. 81-94, 2012. http://dx.doi.org/10.18539/cast.v18i1.2491

IBGE. Pelotas. 2010. Available at: https://cidades.ibge.gov.br/brasil/rs/pelotas/panorama Access: June 2020.

LUÍZ, A. M.; PINTO, M. L. C.; SCHEFFER, E. W. O. Parâmetros de cor e turbidez como indicadores de impactos resultantes do uso do solo, na bacia hidrográfica do rio Taquaral, São Mateus do Sul-PR. Raega, n. 1, p. 290-310, 2012. http://dx.doi.org/10.5380/raega.v24i0.26264

OLIVEIRA, C. N. D.; CAMPOS, V. P.; MEDEIROS, Y. D. P. Avaliação e identificação de parâmetros importantes para a qualidade de corpos d'água no semiárido baiano. Estudo de caso: bacia hidrográfica do Rio Salitre. Química Nova, n. 5, p. 1059-1066, 2010. https://doi.org/10.1590/S0100-40422010000500010 
PIRATOBA, A. R. A.; RIBEIRO, H. M. C.; MORALES, G. P.; GONÇALVES, W. G. Caracterização de parâmetros de qualidade da água na área portuária de Barcarena, PA, Brasil. Revista Ambiente \& Água, n. 3, p. 435-456, 2017. https://doi.org/10.4136/ambiagua. 1910

POST, C. J.; COPE, M. P.; GERARD, P. D.; MASTO, N. M.; VINE, J. R.; STIGLITZ, R. Y.; HALLSTROM, J. O.; NEWMAN, J. C.; MIKHAILOVA, E. A. Monitoring spatial and temporal variation of dissolved oxygen and water temperature in the Savannah River using a sensor network. Environmental Monitoring and assessment, n. 190, p. 272, 2018. https://doi.org/10.1007/s10661-018-6646-y

SILVA, A. P. S.; DIAS, H. C. T.; BASTOS, R. K. X.; SILVA, E. Qualidade da água do Reservatório da Usina Hidrelétrica (UHE) de Peti, Minas Gerais. Revista Árvore, n. 6, p. 1063-1069, 2009. https://doi.org/10.1590/S0100-67622009000600009

SIQUEIRA, G. W.; APRILE, F.; MIGUÉIS, A. M. Diagnóstico da qualidade da água do rio Parauapebas (Pará-Brasil). Acta Amazonica, n. 3, p. 413-422, 2012. https://doi.org/10.1590/S0044-59672012000300014

SIQUEIRA, G. W.; APRILE, F. Avaliação de risco ambiental por contaminação metálica e material orgânico em sedimento do rio Aurá, Região Metropolitana de Belém-PA. Acta Amazonica, n. 1, p. 51-62, 2013. https://doi.org/10.1590/S0044-59672013000100007

SUTADIAN, A. D.; MUTTIL, N.; YILMAZ, A. G.; PERERA, B. J. C. Development of river water quality indices - a review. Environmental Monitoring and Assessment, n. 1, p. 58, 2016. https://doi.org/10.1007/s10661-015-5050-0

SWAMEE, P.; TYAGI, A. Improved method for aggregation of water quality subindices.

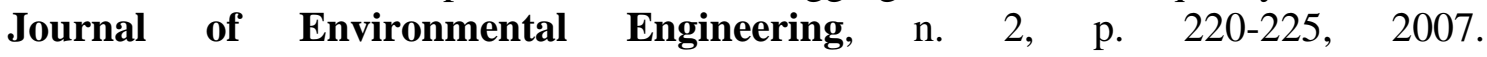
https://doi.org/10.1061/(ASCE)0733-9372(2007)133:2(220)

TANIWAKI, R. H.; CASSIANO, C. C.; FILOSO, S.; DE BARROS FERRAZ, S. F.; DE CAMARGO, P. B.; MARTINELLI, L. A. Impacts of converting low-intensity pastureland to high-intensity bioenergy cropland on the water quality of tropical streams in Brazil. Science Total Environmental, p. 339-347, 2017. https://doi.org/10.1016/j.scitotenv.2016.12.150

TORRES, I. A.; SILVA, T. M. F.; RODRIGUES, L. S.; SILVA, I. J.; COSTA, T. A.; SOTOBLANCO, B.; MELO, M. M. Physicochemical analysis of water, sediment and riparian vegetation of a fish farming located in an agroindustrial area at the border of Ribeirão da Mata. Engenharia Sanitária Ambiental, n. 4, p. 773-780, 2017. https://doi.org/10.1590/s1413-41522017110861

VON SPERLING, M. Wastewater characteristics, treatment and disposal. London: IWA publishing, 2007. 306p.

WANG, J.; LIU, G.; LIU, H.; LAM, P. K. Multivariate statistical evaluation of dissolved trace elements and a water quality assessment in the middle reaches of Huaihe River, Anhui, $\begin{array}{lllll}\text { China. Science Total Environmental, p. 421-431, } 2017 . & \end{array}$ https://doi.org/10.1016/j.scitotenv.2017.01.088

XIAO, J.; WANG, L.; DENG, L.; JIN, Z. Characteristics, sources, water quality and health risk assessment of trace elements in river water and well water in the Chinese Loess Plateau. $\begin{array}{lllll}\text { Science } & \text { Total } & \text { Environmental, } & \text { p. } & \text { 2004-2012, }\end{array}$ https://doi.org/10.1016/j.scitotenv.2018.09.322 